\title{
Wolves, Elk, Bison, and Secondary Trophic Cascades in Yellowstone National Park
}

\author{
William J. Ripple ${ }^{*}, 1$, Luke E. Painter ${ }^{1}$, Robert L. Beschta ${ }^{1}$ and C. Cormack Gates ${ }^{2}$ \\ ${ }^{1}$ Department of Forest Ecosystems and Society, Oregon State University, Corvallis, Oregon 97331, USA \\ ${ }^{2}$ Faculty of Environmental Design, University of Calgary, Calgary, Alberta, USA
}

\begin{abstract}
Wolves were reintroduced into Yellowstone National Park in 1995/96, likely reestablishing a trophic cascade involving wolves, elk, and woody browse species. The return of wolves may have also triggered a secondary trophic cascade involving bison, which are generally a minor prey species for wolves in northern Yellowstone. We hypothesize a sequence of events in northern Yellowstone where: 1) wolves prey on elk, changing elk behavior and reducing elk numbers, 2) causing reduced elk herbivory and more forage available to bison, and 3) allowing higher bison densities and additional bison effects on the ecosystem. This secondary trophic cascade, whereby wolf predation may have indirectly allowed bison numbers to increase through a reduction in inter-specific competition with elk, may represent an example of an alternative top-down pathway by which predators can influence multiple trophic levels through mediating the competitive interaction between two prey species. Both wolves and bison can have important effects on ecosystems, and there is growing interest in restoring these animals to wider portions of their former range. However, there are many potential routes for interactions between species and it is important to consider the conservation implications of other cascading effects when reintroducing such ecologically influential species into wild landscapes. The potential benefits of bison to their native ecosystems may not be realized in situations with low predation pressure, high bison densities, and constraints on bison movement and migration, thus likely contributing to impairment of resources.
\end{abstract}

Keywords: Wolves, elk, bison, trophic cascades, Yellowstone, secondary trophic cascade, riparian, biodiversity.

\section{INTRODUCTION}

Trophic cascades occur when the presence of a top predator substantially affects consumer (herbivore) behavior or population size, thereby influencing producer (plant) abundance, structure, or spatial distribution. Wolves (Canis lupus) were reintroduced into Yellowstone National Park during the winters of 1995 and 1996 following approximately seven decades of absence. During that seven decade period, palatable woody browse plants were highly suppressed on the Park's northern range (Ripple and Larsen 2000, National Research Council 2002, Barmore 2003, Beschta 2005). Within ten years of increasing wolf presence and declining elk (Cervus elaphus) populations, there was evidence suggesting that a trophic cascade caused a reduced level of elk browsing on willow (Salix spp.), aspen (Populus tremuloides), and cottonwood (Populus angustifolia and P. trichocarpa) allowing young plants to grow taller in portions of the Park's northern range (Singer et al. 2003, Ripple and Beschta 2006, Beyer et al. 2007, Ripple and Beschta 2007, Beschta and Ripple 2010). In addition to a decreasing elk population since wolf reintroduction, elk behavior and foraging patterns appear to have changed (Laundre et al. 2001, Hernandez and Laundre 2005), with less browsing

*Address correspondence to this author at the Department of Forest Ecosystems and Society, Oregon State University, Corvallis, Oregon 97331, USA; Tel: 541737 3056; Fax: 541737 1393; E-mail: bill.ripple@oregonstate.edu

Guest Editor: John W. Laundre along some streams and valley bottoms of the northern range (Beyer 2006, Ripple and Beschta 2006), and an increasing proportion of the northern Yellowstone elk herd wintering in the lower, western part of the range away from Lamar Valley, both in and out of the Park boundary (White et al. 2010).

The objective of this manuscript is to present a new hypothesis concerning wolf-triggered trophic cascades in Yellowstone based on our analysis of elk and bison (Bison bison) population trends, field studies, and available literature. We describe ecological implications of this potential cascade, alternative hypotheses, and recommend additional work.

\section{BISON AND SECONDARY TROPHIC CASCADES}

Concurrent with the recent decline in elk population and altered patterns of habitat use, the bison population has been increasing on the northern range (Fig. 1). Why would these opposite trends exist? Bison are currently not a major prey species for wolves in Yellowstone's northern range, making up only a minor portion of the wolf kills (4\% in 2008), while elk comprise a majority of the wolf diet (80\% in 2008; Smith et al. 2009). Since there is competitive dietary overlap between Yellowstone's elk and bison (Singer and Norland 1994), and bison populations in Yellowstone are foragelimited (Gates et al. 2005, Fuller et al. 2007), some have suggested that wolf predation could cause bison numbers to increase through a reduction in inter-specific competition with elk for forage (Coughenour 2005, Gates et al. 2005, 


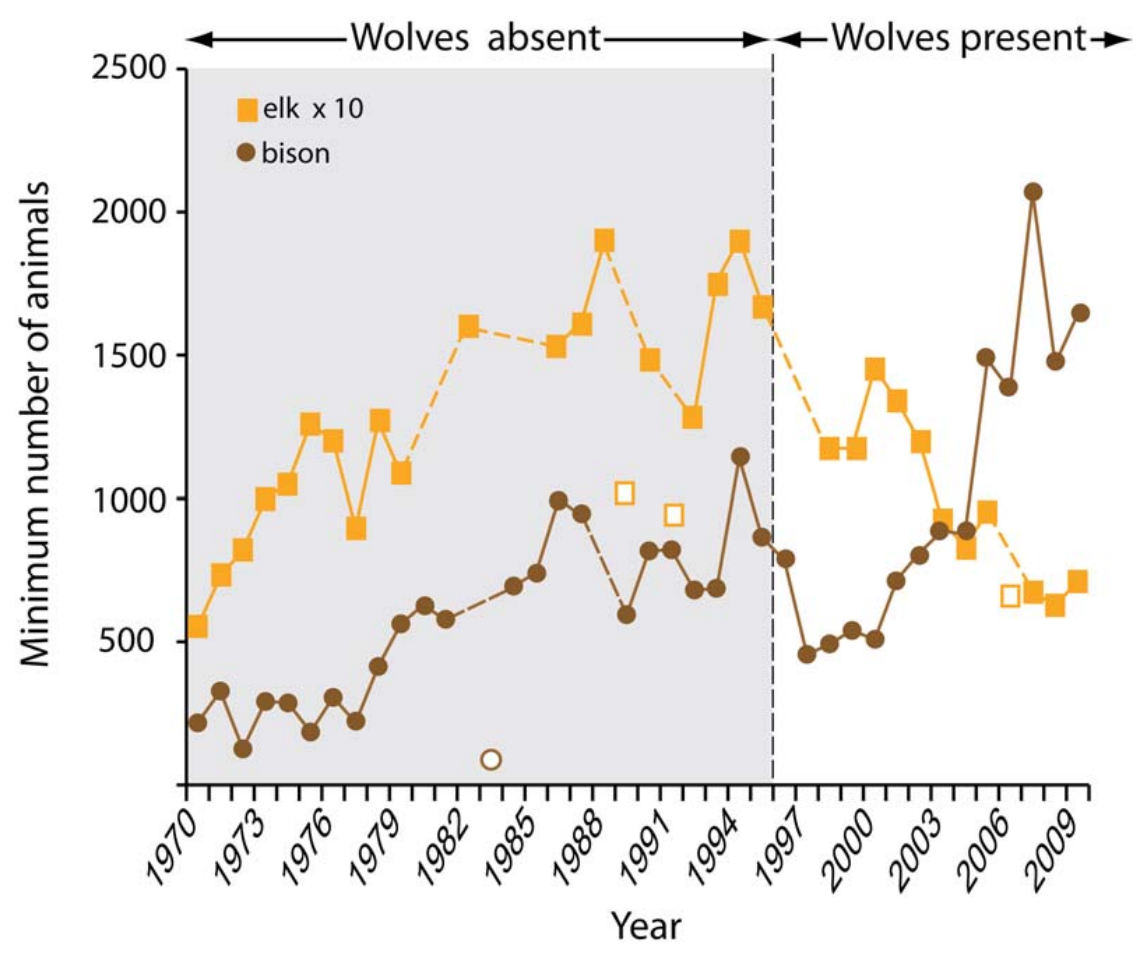

Fig. (1). Northern range elk and bison population trends. The open boxes and squares represent ungulate surveys that were likely inaccurate due to poor count conditions.

White and Garrott 2005). We posit that such a change may now be underway and that wolf reintroduction is triggering another (secondary) trophic cascade extending to bison and the plants bison consume in the Lamar Valley portion of the northern range.

We hypothesize a series of related events in the Lamar Valley, which we term a secondary trophic cascade, where: 1) wolves prey on elk, changing elk behavior and habitat selection, and reducing elk numbers; 2) causing reduced elk herbivory and more forage available to bison; thus 3 ) allowing higher bison densities and additional bison effects on the ecosystem from herbivory, trampling and wallowing. Herein we limit our discussion to trophic interactions involving bison, but we note herbivores such as bighorn sheep (Ovis canadensis), lagomorphs, beaver (Castor canadensis), mule deer (Odocoileus hemionus), moose (Alces alces) and others could also be affected due to decreasing elk populations or changing predator/prey dynamics. For example, lower elk numbers in northern Yellowstone since wolf reintroduction may have resulted in less competition for forage between elk and bighorn sheep, allowing the sheep population to increase (White et al. 2008). Although, the potential impact of predators on prey competition has been recognized since the 1960's (Paine 1966), we found little documentation of a secondary trophic cascade where, following the reestablishment of a top predator, a second herbivore is released from competition pressure and increases after a decline of the primary prey. There are many potential routes for interactions between species, and this secondary trophic cascade may represent an example of a little-known alternative top-down pathway by which large carnivores can influence ecosystems (Holt and Lawton 1994).
To investigate the secondary trophic cascade hypothesis, we conducted a regression analysis of the northern range elk population (independent variable) with the bison population (dependent variable) for a period before wolf reintroduction (1970-1995) and another after wolf reintroduction (19982010). The pre-wolf regression showed a direct relationship between elk and bison populations with a positive correlation (as elk increase, bison increase, $r=0.77$ ). Consistent with the trophic cascade hypothesis, results for the period following wolf reintroduction showed a strong inverse relationship $(\mathrm{r}=$ -0.84 ) between elk numbers and bison numbers (as elk decrease, bison increase - Fig. 2). Using multiple regression to test for a difference in slopes, this change in the relationship between elk and bison numbers before wolves versus after wolves was highly significant $(\mathrm{p}<0.001)$.

Much of the relatively large increase in bison on the northern range since the late 1990's may be due to immigration from Yellowstone's central herd (Taper et al. 2000, Gates et al. 2005, Plumb et al. 2009). Apparently, there were smaller pulses of emigration from the central herd to the northern herd between 1982 and the late 1990's in response to limited resources for the central herd (Fuller et al. 2007). The emigration idea is supported by recent observations of marked individuals from the Park's central herd showing up on the northern range (Wallen 2009). In 2009, park officials enumerated fewer bison in the central herd than the northern herd for the first time since the park started repeat aerial surveys in 1970. Could bison be increasingly migrating to the northern range, since wolf reintroduction, to capitalize on increasing forage availability due to a decreasing elk population and changes in elk movements and foraging patterns? As others predicted, we believe that this may now be the case, and that there are 


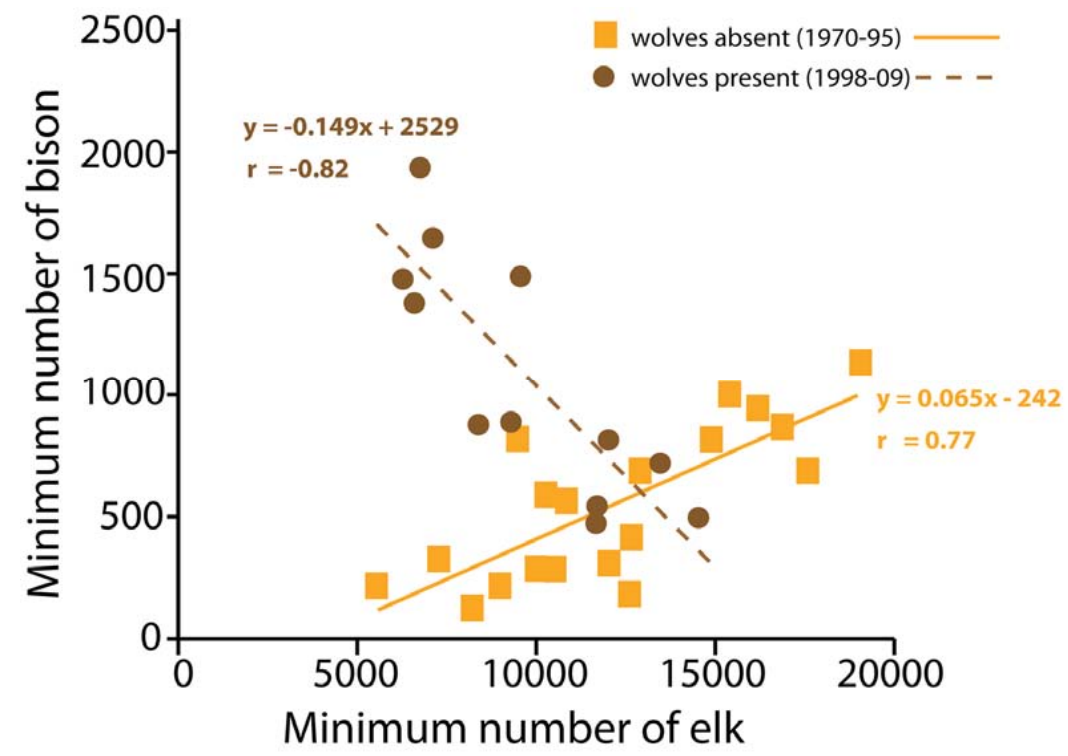

Fig. (2). Scatter diagram showing how the relationship between bison and elk numbers for the northern range changed after the reintroduction of wolves.

associated ecological, conservation, and management implications.

Bison movement to the northern range in recent years may have been influenced by use of groomed roads in winter. Bison from the central range, which has deep snow, have learned to follow a groomed road through high snow country to a winter range with low snow (northern range). The origin of learning this route was likely the harsh winter of 1997 when large numbers first moved north from the central range on the road from Madison Junction to Mammoth (Taper et al. 2000, Meagher et al. 2002). Both weather-driven opportunism and destination-oriented migration could now be involved. Furthermore, since central herd animals are familiar with the northern range destination, they may adopt early (pre-snow season) calculated migratory behavior, even if the road is not groomed. The deeper snow packs of the central range make bison more vulnerable to wolf predation, and these bison experience more wolf predation pressure than those on the northern range (Garrott et al. 2009). This difference in wolf predation risk may also be contributing to bison emigration from the central range.

A portion of the increase of the northern bison herd may have been independent of immigration. If there was a release of forage from reduced herbivory by elk, then bison rate of increase could have risen owing to greater per capita forage availability. However, we have no way of knowing how much of the increase in abundance of bison on the northern range is attributable to birth/death rate changes for animals in situ versus immigration from the central range population.

The recent increase of bison on the northern range may have implications for woody plants and riparian conditions. Conventional wisdom suggests that bison are predominately grazers and generally do little browsing on willows and other woody plants (Knapp et al. 1999, Shaw and Meagher 2000). However, on some ranges where woody browse is abundant, high consumption of browse by bison has been reported (Miquelle 1985, Larter and Gates 1991). Waggoner and Hinkes (1986) examined the food habits of a small Alaskan bison herd and found the diet to consist of $94 \%$ willow in summer, and $68 \%$ willow and other shrubs in fall. In summer, woody browse may be the most available source of crude protein, an important nutritional factor for grazing ungulates (Larter and Gates 1991).

Meagher (1973) examined rumen samples from 22 Yellowstone bison and found that sedges were the main source of forage, followed by grasses, the two together accounting for more than $90 \%$ of bison diet. Singer and Norland (1994) found less than $1 \%$ of cottonwood, aspen and willow in the diet of any ungulate species on the northern range, probably because these woody plant species were rare in the study area. In contrast to the findings of these diet studies, we have frequently observed bison browsing willows in the Lamar Valley in both summer (Fig. 3a) and winter (Fig. 3b). Furthermore, bison may be suppressing willow growth in some areas, thus continuing the effects from elk that occurred prior to the reintroduction of wolves. For example, Ripple and Beschta (2006) found the number of bison flops to be inversely and significantly correlated with willow height in the Lamar Valley. At a site near the confluence of Soda Butte Creek and the Lamar River, we found $87 \%$ of the Bebb willow (Salix bebbiana) clumps were browsed in the summer of 2009 at heights below $1 \mathrm{~m}$, within the reach of bison (Fig. 3c) (author's unpublished data). On some stems, this browsing removed both the entire current year's growth and part of the previous year's stem growth. We attributed this herbivory to bison because they were the only ungulates present in large numbers in the Lamar Valley during the summer season, their scat was highly abundant in the area, and we observed them browsing these willows. We have also noticed high levels of summer browsing in the Lamar Valley on cottonwood seedlings, aspen sprouts, rose (Rosa sp.), twinberry (Lonicera invoucrata), shrubby cinquefoil (Potentilla fruticosa) and other woody plants. Finally, we observed recent impacts to streambank structure due to bison trampling (Fig. 3d). 

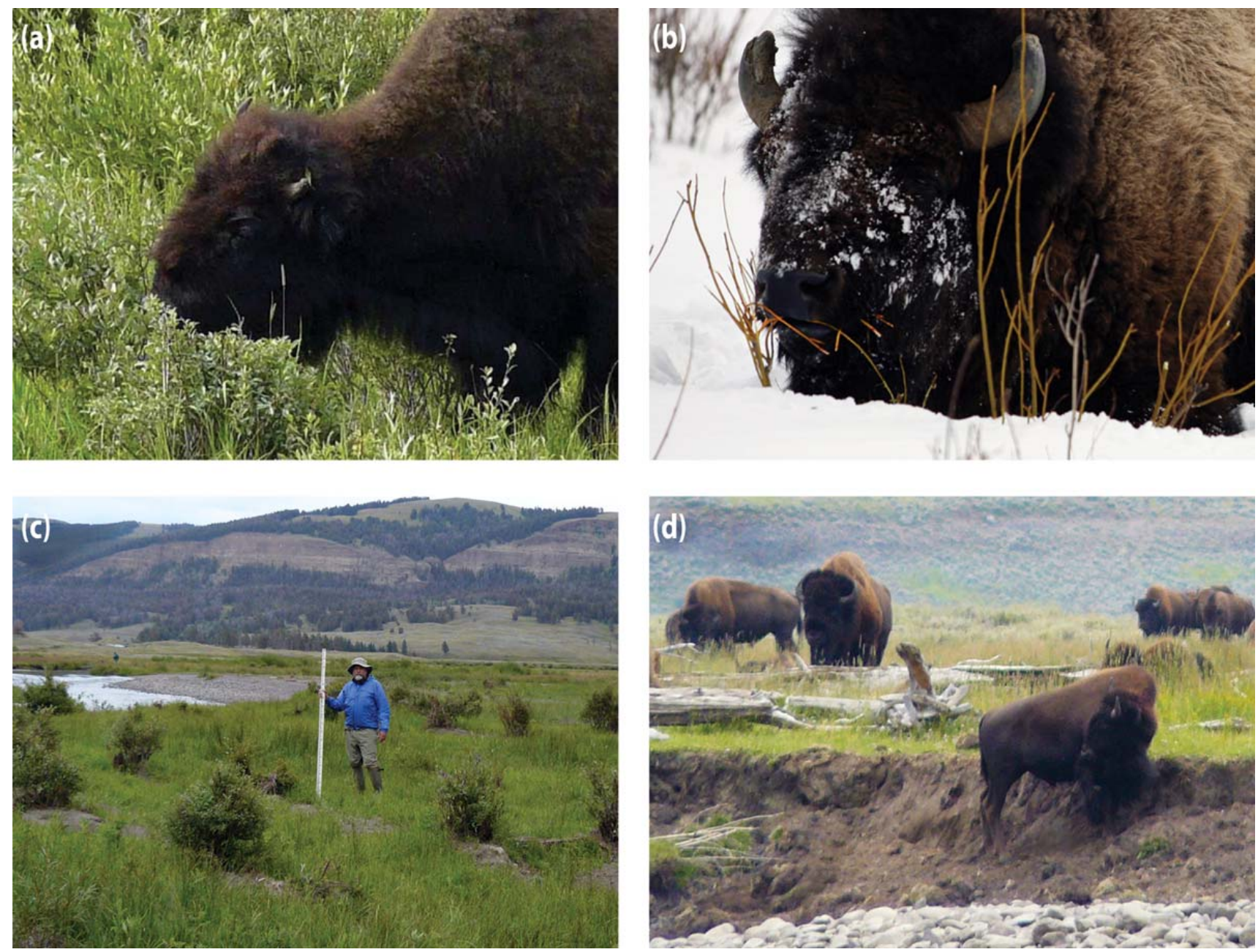

Fig. (3). Photographs showing both (a) summer bison browsing, (b) winter bison browsing, (c) hedged Bebb willows, likely from bison browsing, and (d) eroding streambank in the Lamar Valley. Sources: W.J. Ripple—(Fig. 3a, 3c, 3d), Yellowstone National Park-(Fig. 3b).

White and Garrott (2005) concluded: "If elk abundance on the northern range of Yellowstone continues to decrease during the near future, ...then the change to the system will almost certainly lead to the amelioration of any ungulatecaused landscape simplification such as the decreased riparian habitat, beaver wetlands, and aspen recruitment." We concur with this statement for sites on the northern range avoided by bison, but this is unlikely to be the case for areas on the northern range with heavy bison use, because it appears that bison are browsing woody plants and may be assuming the role of dominant herbivore (Beschta and Ripple 2010). While the return of wolves appears to have reduced browsing effects of elk, the trophic cascades involving bison have not been fully considered, and these large herbivores now appear to be having significant effects on plant communities, especially on floodplains and riparian areas.

\section{ALTERNATIVE HYPOTHESES}

The correlation between decreasing elk and increasing bison populations on the northern range could be an indication of the release of bison from competition with elk, but other explanations are possible. After culling of elk and bison inside the park was suspended in 1967, and before the return of wolves, both elk and bison populations generally increased until the mid 1980's (Taper et al. 2000, Gates et al. 2005, Garrott et al. 2009). Could bison have simply continued to increase, unrelated to the decrease in elk on the northern range? This is unlikely because bison numbers did not increase substantially on the northern range during the decade before wolf reintroduction (Fig. 1). Some have speculated that this lack of increase was likely due to "the dominant effect of forage competition by a large elk population" (p. vii, Gates et al. 2005).

Since the cessation of culling within the Park in 1967, the primary factor limiting bison populations has been culling outside the Park boundaries, when bison attempt to migrate to lower-elevation winter ranges (Peacock 1997, Gates et al. 2005, Fuller et al. 2007). A reduction in bison culling could allow bison to increase, but the number of bison culled has been as high or higher for the period after wolf reintroduction (1998-2009) compared to before wolf reintroduction (1984-1995) (Plumb et al. 2009). In both 2005 and 2007 there were large reductions in the Park herd, and the number of bison culled in 2007 was larger than in any previous year. 
Milder winters could contribute to a bison increase, by reducing winter losses and allowing bison to remain in the park. However, we analyzed the accumulated daily snowwater equivalent $\left[\mathrm{SWE}_{\mathrm{acc}}\right.$, see Garrott et al. (2003) for methods] data from two NRCS SNOTEL sites nearest the northern range (Northeast Entrance Site 10d07 and Canyon Site $10 \mathrm{e} 03 \mathrm{~s}$ ), and found no significant difference (t-test, $\mathrm{p}=$ 0.92 ) between mean $\mathrm{SWE}_{\text {acc }}$ for the 12 years before wolf reintroduction (1984-95, mean $32.3 \mathrm{~m}$ ) versus after wolf reintroduction (1998-2009, mean $31.5 \mathrm{~m})$. SWE $\mathrm{SWc}_{\mathrm{acc}}$ was unusually high in 1996 and 1997, averaging $64.0 \mathrm{~m}$, and bison numbers dropped by more than half on the northern range as bison migrated out of the park and were culled, or starved in the deep, crusted snows (Peacock 1997, Shaw and Meagher 2000). Bison numbers subsequently rebounded (Fig. 1).

\section{ECOLOGICAL IMPLICATIONS}

The presence of central range animals wintering on the northern range represents intra-specific competition with potential effects on the ecosystem. Since some central range bison have remained on the northern range in summer (i.e., they have shifted their summer range from the central part of the Park), the effects of bison herbivory on the northern range may be increased. Typically, bison cows show high fidelity to summer ranges, but range shifts can occur as a density-driven phenomenon (Gates and Larter 1990, Meagher et al. 2002, Fuller et al. 2007).

The increase of bison on the northern range may have significant ecological implications, because some of the effects of bison are different from those of the elk they are replacing. One important difference is that bison herds are now present in larger numbers in both summer and winter in the Lamar Valley area, whereas elk utilize the northern range primarily in winter (National Research Council 2002, Gates et al. 2005). Bison browsing of willow, aspen, cottonwood and other woody species in summer has the potential to remove the current year's growth as it occurs, giving the plants little opportunity to recover. In contrast, elk on the northern range remove portions of stems after they have become dormant for the winter, which allows plants to replace at least part of the lost biomass the following summer. Bison presence in riparian areas in the summer may also result in more trampling and erosion of stream banks than has typically resulted from winter use by elk because: 1 ) bison are much larger, heavier animals than elk, 2) a large portion of the bison diet is sedges, so bison are frequently found in wetlands and riparian areas, and 3) summertime riparian use by bison may be high due to increased water intake requirements during warm weather. In upland areas, intensive grazing by bison herds may result in a decline in favored forage species, an increase in non-native species, and an increase in soil erosion (Taper et al. 2000). Bison also create wallows, causing soil disturbance, compaction and increased landscape heterogeneity (Knapp et al. 1999, Butler 2006), and bison horning and rubbing on shrubs and trees can affect the growth and persistence of woody plants (Coppedge and Shaw 1997, Olenicki and Irby 2003).

The effects of browsing for bison and elk on plants can differ in other ways. For example, the height at which plant stems grow above browse level is approximately $2 \mathrm{~m}$ for elk and $1 \mathrm{~m}$ for bison (author's unpublished data). Therefore, plant stems may grow above the browse level of bison sooner than the browse level of elk. While elk consume aspen bark in winter and this behavior has not been reported for bison, bison rubbing can significantly damage the bark of established trees.

Wolf predation may affect bison differently than elk, both through effects on population size as well as behavior and habitat selection. Bison attacked by wolves will frequently form a defensive group, rather than fleeing as elk do (Carbyn and Trottier 1988, Carbyn et al. 1993, Smith et al. 2006, Becker et al. 2009, Garrott et al. 2009), and individual adult bison are more likely to successfully resist attack (MacNulty et al. 2007). Also, wolf predation on elk in the Yellowstone area has been mainly additive, reducing the elk population, whereas, so far, predation on bison has probably been mostly compensatory, having little impact on bison numbers (White and Garrott 2005, Garrott et al. 2009, White et al. 2010). These differences in response to predation may cause differences in potential trophic cascades, both density-driven and behavioral (Laundre et al. 2010).

In Wood Buffalo National Park (WBNP), Alberta, Canada, where bison are the primary prey of wolves, wolf predation has reduced bison numbers, although cattle diseases may also be a contributing factor (Carbyn et al. 1993, Joly and Messier 2004, Bradley and Wilmshurst 2005). Thus, the eventual effect of increased bison numbers in northern Yellowstone may be to relieve wolves from density-dependence on elk and to maintain pressure on elk when they are available, as seems to already be the case in central Yellowstone (White and Garrott 2005, Smith et al. 2006, Garrott et al. 2009). If wolves become successful with this prey-switching tactic between elk and bison, they could eventually bring northern range elk numbers to very low levels (apparent competition) as has been seen with moose in the wolf/bison/moose system of Mackenzie Bison Sanctuary in the Northwest Territories, Canada (Larter et al. 1994). Apparent competition has been documented in numerous systems and occurs when two prey species share a common predator and an increase in an alternative prey species allows predators to increase, leading to a decrease in the focal prey species (Holt and Lawton 1994). Higher bison numbers may also result in an increase in the number of vulnerable bison, increasing the subsidy to wolves and the pressure on elk. However, to date wolves in Yellowstone's northern range have continued to show a strong preference for elk. Another possibility is that northern Yellowstone elk will become less vulnerable to wolf predation over time, thereby allowing elk numbers to stabilize or increase.

Bison, as the largest North American species to survive the megafaunal extinctions of the late Pleistocene, were prey for very large and fierce carnivores such as dire wolves (Canis dirus), sabertooth cats (Smilodon fatalis), and American lions (Panthera leo atrox) (Ripple and Van Valkenburgh 2010). After the extinction of these large carnivores, human hunters and gray wolves were the main predation forces on bison. Predation pressure on bison today is much less than it was in early times with a lack of these natural enemies from the Pleistocene as well as the more recent aboriginal hunters during the Holocene. Another 
difference is that historically bison were a nomadic species, a trait that may have allowed escape from predation limitations, with very different ecosystem effects than for nonmigrating populations. Some human hunters may have followed bison migrations, further increasing the complexity of predator-prey interactions. It is unknown how often and under what circumstances gray wolves alone might be able to limit contemporary bison populations.

Bison can have important ecological effects, and have been called a foundation species or highly interactive species capable of producing significant changes in an ecosystem (Knapp et al. 1999, Soulé et al. 2003). The effects of bison occur at both large and small spatial scales, and include increased vegetation heterogeneity, nutrient redistribution, changes in plant species composition, creation and maintenance of grasslands, increased productivity in grasslands, competition with other herbivores, modification of fire regimes, modification of hydrological processes, and disturbance of woody vegetation (Hartnett et al. 1996, Coppedge and Shaw 1997, Knapp et al. 1999, Butler 2006, Sanderson et al. 2008, Gates et al. 2010). These influences may change wildlife habitat in ways that support some species and limit others, producing cascading effects on biodiversity and species composition. However, the potential benefits of bison to ecosystems may not be realized in situations with high bison densities, year-round use, low predation pressure, and constraints on bison movements, because chronic high densities of bison can affect native flora and fauna in ways similar to domestic livestock, thus contributing to impairment of resources (Knapp et al. 1999).

Bison may be replacing elk as the dominant herbivore in portions of Yellowstone National Park and there is the likelihood of a secondary trophic cascade occurring. Consequently, understanding bison effects on ecosystems is of increasing importance. Historically, bison were a critical and foundational influence on the ecology of their native habitat, but this relationship was likely mediated by higher levels of predation, and large-scale movements, factors that are diminished today. Recent bison research and management has focused on issues related to population dynamics, brucellosis (Brucella abortus) disease, and patterns of movement in and out of the Park, with little attention to the ecological effects of bison. We recommend that future bison research and management, both in Yellowstone and other bison ranges throughout North America, consider the important effects of bison on ecosystems, including relationships between bison and woody plant communities, riparian areas, beaver habitat, soil stability, stream channel morphology, and biological diversity.

\section{REFERENCES}

Barmore, WJ (2003) Ecology of Ungulates and their Winter Range in Northern Yellowstone National Park; Research and Synthesis 1962-1970, Yellowstone Center for Resources, Yellowstone National Park.

Becker, MS, Garrott, RA, White, PJ, Gower, CN, Bergman, EJ \& Jaffe, R (2009) Wolf prey selection in an elk-bison system: choice or circumstance? In: Garrott, RA, White, PJ \& Watson, FGR (Eds) The Ecology of Large Mammals in Central Yellowstone: Sixteen Years of Integrated Field Studies, Academic Press/Elsevier: Boston, 305-37.
Beschta, RL (2005) Reduced cottonwood recruitment following extirpation of wolves in Yellowstone's northern range. Ecology, 86, 391403.

Beschta, RL \& Ripple, WJ (2010) Recovering riparian plant communities with wolves in northern Yellowstone, USA. Restoration Ecology, 18, 380-9.

Beyer, HL (2006) Wolves, elk and willow on Yellowstone National Park's northern range. M.S. Thesis. University of Alberta: Edmonton.

Beyer, HL, Merrill, EH, Varley, N \& Boyce, MS (2007) Willow on Yellowstone's northern range: evidence for a trophic cascade? Ecological Applications, 17, 1563-71.

Bradley, M \& Wilmshurst, J (2005) The fall and rise of bison populations in Wood Buffalo National Park: 1971 to 2003. Canadian Journal of Zoology, 83, 1195-205.

Butler, DR (2006) Human-induced changes in animal populations and distributions, and the subsequent effects on fluvial systems. Geomorphology, 79, 448-59.

Carbyn, LN, Oosenbrug, SM \& Anions, DW (1993) Wolves, Bison and the Dynamics Related to the Peace-Athabasca Delta in Canada's Wood Buffalo National Park, Circumpolar Institute, University of Alberta: Edmonton.

Carbyn, LN \& Trottier, T (1988) Descriptions of wolf attacks on bison calves in Wood Buffalo National Park. Arctic, 41, 297-302.

Coppedge, BR \& Shaw, JH (1997) Effects of horning and rubbing behavior by bison (Bison bison) on woody vegetation in a tallgrass prairie landscape. American Midland Naturalist, 138, 189-96.

Coughenour, MB (2005) Bison and Elk in Yellowstone National Park Linking Ecosystem, Animal Nutrition, and Population Processes, Part 2, Final Report to U.S. Geological Survey, Biological Resources Division: Bozeman.

Fuller, JA, Garrott, RA \& White, PJ (2007) Emigration and density dependence in Yellowstone bison. Journal of Wildlife Management, 71, 1924-33.

Garrott, RA, Eberhardt, LL \& White, PJ (2003) Climate-induced variation in vital rates of an unharvested large-herbivore population. Canadian Journal of Zoology, 81, 33.

Garrott, RA, White, PJ \& Watson, FGR (Eds) (2009) The Ecology of Large Mammals in Central Yellowstone: Sixteen Years of Integrated Field Studies. Academic Press/Elsevier: Boston.

Gates, CC, Freese, CH, Gogan, PJ \& Kotzman, M (Eds) (2010) American Bison: Status Survey and Conservation Guidelines 2010. IUCN, Gland: Switzerland.

Gates, CC \& Larter, NC (1990) Growth and dispersal of an erupting large herbivore population in Northern Canada: The Mackenzie wood bison (Bison bison athabascae). Arctic, 43, 231-328.

Gates, CC, Stelfox, B, Muhly, T, Chowns, T \& Hudson, RJ (2005) The Ecology of Bison Movements and Distribution In and Beyond Yellowstone National Park, University of Calgary: Alberta.

Hartnett, DC, Hickman, KR \& Walter, LE (1996) Effects of bison grazing, fire, and topography on floristic diversity in tallgrass prairie. Journal of Range Management, 49, 413-20.

Hernandez, L \& Laundre, JW (2005) Foraging in the 'landscape of fear', and its implications for habitat use and diet quality of elk Cervus elaphus and bison Bison bison. Wildlife Biology, 11, 215-20.

Holt, RD \& Lawton, JH (1994) The ecological consequences of shared natural enemies. Annual Review of Ecology and Systematics, 25, 495-520.

Joly, DO \& Messier, F (2004) Testing hypotheses of bison population decline (1970-1999) in Wood Buffalo National Park: synergism between exotic disease and predation. Canadian Journal of Zoology, 82, 1165-76.

Knapp, AK, Blair, JM, Briggs, JM, Collins, SL, Hartnett, DC, Johnson, LC \& Towne, EG (1999) The keystone role of bison in North American tallgrass prairie. Bioscience, 49, 39-50.

Larter, NC \& Gates, CC (1991) Diet and habitat selection of wood bison in relation to seasonal changes in forage quantity and quality. Canadian Journal of Zoology, 69, 2677-85.

Larter, NC, Sinclair, ARE \& Gates, CC (1994) The response of predators to an erupting bison, Bison bison athabascae, population. Canadian Field-Naturalist, 108, 318-27.

Laundre, JW, Hernandez, L \& Altendorf, KB (2001) Wolves, elk, and bison: reestablishing the "landscape of fear" in Yellowstone National Park, USA. Canadian Journal of Zoology, 79, 1401-9.

Laundre, JW, Hernandez, L \& Ripple, WJ (2010) The landscape of fear: ecological implications of being afraid. Open Ecology Journal, $3,1-7$. 
MacNulty, DR, Mech, LD \& Smith, DW (2007) A proposed ethogram of large-carnivore predatory behavior, exemplified by the wolf. Journal of Mammalogy, 88, 595-605.

Meagher, MM (1973) The Bison of Yellowstone National Park, National Park Service, Scientific Monograph Series Number 1. Government Printing Office: Washington, DC.

Meagher, MM, Taper, ML \& Jerde, CL (2002) Recent changes in population distribution: the Pelican bison and the domino effect, In: Yellowstone Lake: Hotbed of Chaos or Reservoir of Resilience? 6th Biennial Scientific Conference on the Greater Yellowstone Ecosystem (2001), Yellowstone National Park, National Park Service, 135-37.

Miquelle, D (1985) Food Habits and Range Conditions of Bison and Sympatric Ungulates on the Upper Chitina River, Wrangell-St. Elias National Park and Preserve, National Park Service, Alaska Regional Office: Anchorage.

National Research Council (2002) Ecological Dynamics on Yellowstone's Northern Range, National Academy Press: Washington DC.

Olenicki, TJ \& Irby, LR (2003) Determining forage availability and use patterns for bison in the Hayden Valley of Yellowstone National Park, Fish and Wildlife Management Program, Ecology Department, Montana State University: Bozeman.

Paine, RT (1966) Food web complexity and species diversity. American Naturalist, 100, 65-75.

Peacock, D (1997) The Yellowstone massacre. Audubon, 99, 40-9.

Plumb, GE, White, PJ, Coughenour, MB \& Wallen, RL (2009) Carrying capacity, migration, and dispersal in Yellowstone bison. Biological Conservation, 142, 2377-87.

Ripple, WJ \& Beschta, RL (2006) Linking wolves to willows via risksensitive foraging by ungulates in the northern Yellowstone ecosystem. Forest Ecology and Management, 230, 96-106.

Ripple, WJ \& Beschta, RL (2007) Restoring Yellowstone's aspen with wolves. Biological Conservation, 138, 514-19.

Ripple, WJ \& Larsen, EJ (2000) Historic aspen recruitment, elk, and wolves in northern Yellowstone National Park, USA. Biological Conservation, 95, 361-70.

Ripple, WJ \& Van Valkenburgh, B (2010) Linking top-down forces to the Pleistocene megafaunal extinctions. Bioscience, 60, 516-26.

Sanderson, EW, Redford, KH, Weber, B, Aune, KE, Baldes, D, Berger, J, Carter, D, Curtin, C, Derr, JN, Dobrott, S, Fearn, E, Fleener, C, Forrest, SC, Gerlach, C, Gates, CC, Gross, JE, Gogan, PJP, Grassel, S, Hilty, JA, Jensen, M, Kunkel, K, Lammers, D, List, R, Minkowski, K, Olson, T, Pague, C, Robertson, PB \& Stephenson, B (2008) The ecological future of the North American bison: conceiving long-term, large-scale conservation of wildlife. Conservation Biology, 22, 252-66.

Shaw, JH \& Meagher, M (2000) Bison, In: Demarais, S \& Krauseman, PR (Eds.) Ecology and management of large mammals in North America, New York: Prentice Hall, 447-66.
Singer, FJ \& Norland, JE (1994) Niche relationships within a guild of ungulate species in Yellowstone National Park, Wyoming, following release from artificial controls. Canadian Journal of Zoology, 72, 1383-94.

Singer, FJ, Wang, G \& Hobbs, NT (2003) The role of grazing ungulates and large keystone predators on plants, community structure, and ecosystem processes in national parks, In: Zabel, CJ \& Anthony, RG (Eds) Mammal Community Dynamics: Conservation and Management in Coniferous Forests of Western North America, New York: Cambridge University Press, 444-86.

Smith, DW, Stahler, DR, Albers, E, Metz, M, Williamson, L, Ehlers, N, Cassidy, K, J. Irving, Raymond, R, Almberg, E \& McIntyre, R (2009) Yellowstone Wolf Project: Annual Report, 2008, National Park Service, Yellowstone Center for Resources: Yellowstone National Park, WY.

Smith, DW, Stahler, DR, Guernsey, DS \& Bangs, E (2006) Wolf Restoration in Yellowstone National Park, In: McCullough, DR, Kaji, K \& Yamanaka, M (Eds.) Wildlife in Shiretoko and Yellowstone National Parks: Lessons in Wildlife Conservation from two World Heritage sites, Hokkaido, Japan: Shiretoko Nature Foundation, 242-53.

Soulé, ME, Estes, JA, Berger, J \& Martinez Del Rio, C (2003) Ecological effectiveness: conservation goals for interactive species. Conservation Biology, 17, 1238-50.

Taper, ML, Meagher, MM \& Jerde, CL (2000) The Phenology of Space: Spatial Aspects of Bison Density Dependence in Yellowstone National Park, National Park Service: Yellowstone National Park, WY.

Waggoner, V \& Hinkes, M (1986) Summer and fall browse utilization by an Alaskan bison herd. Journal of Wildlife Management, 50, 322423.

Wallen, RL (2009) Abundance and Distribution of Yellowstone Bison, July 2009, Yellowstone Center for Resources: Yellowstone National Park, WY

White, PJ \& Garrott, RA (2005) Yellowstone's ungulates after wolves expectations, realizations, and predictions. Biological Conservation, 125, 141-52.

White, PJ, Lemke, TO, Tyers, DB \& Fuller, JA (2008) Initial effects of reintroduced wolves Canis lupus on bighorn sheep Ovis canadensis dynamics in Yellowstone National Park. Wildlife Biology, 14, 138-46.

White, PJ, Proffitt, KM, Mech, LD, Evans, SB, Cunningham, JA \& Hamlin, KL (2010) Migration of northern Yellowstone elk: implications of spatial structuring. Journal of Mammalogy, 91, 827-37.

(C) Ripple et al.; Licensee Bentham Open

This is an open access article licensed under the terms of the Creative Commons Attribution Non-Commercial License (http://creativecommons.org/licenses/bync/3.0/), which permits unrestricted, non-commercial use, distribution \& reproduction in any medium, provided the work is properly cited. 